\title{
Epidemiological Profile and Classification of Autoimmune Diseases in an Internal Medicine Service in Lomé (Togo)
}

\section{Komi Dzidzonu Nemi ${ }^{1 *}$, Lihanimpo Djalogue ${ }^{2}$, Abou Bakari Tchala ${ }^{1}$, Toyi Tchamdja ${ }^{2}$, Kossi Kodjo' ${ }^{1}$, Abdou Razak Moukaila ${ }^{1}$, Komi Edem Mossi $^{1}$, Kodjo Agbéko Djagadou ${ }^{1}$, Abago Balaka ${ }^{1}$ and Mohaman Awalou Djibril ${ }^{\mathbf{1}}$}

${ }^{1}$ Department of Internal Medicine, Sylvanus Olympio Teaching Hospital of Lomé, University of Lomé, Togo

${ }^{2}$ Department of Internal Medicine, Kara Teaching Hospital, University of Kara, Togo

*Corresponding Author: Komi Dzidzonu Nemi, Internal Medicine, Sylvanus Olympio Teaching Hospital of Lomé, University of Lomé, Lomé, Togo.
Received: April 03, 2020

Published: April 24, 2020

(c) All rights are reserved by Komi Dzidzonu Nemi., et al.

\begin{abstract}
The purpose of this study was to describe the epidemiology and classification of autoimmune diseases in the department of Internal Medicine of Sylvanus Olympio teaching hospital of Lomé. This is a retrospective study conducted from $1^{\text {st }}$ January 2018 to December $31^{\text {st }} 2019$ in this department. During the study period, 959 patients were received in the department. Among them, 72 had autoimmune diseases, i.e. a prevalence of 7.5\%. The average age of the patients was 31.51 years (range: 17 and 74) and the sex ratio (M/F) was 0.46 . The 20 to 39 age group was the most represented (69.44\%). Organ-specific autoimmune diseases were type 1 diabetes mellitus $(\mathrm{N}=48 ; 66.7 \%)$, Graves' disease $(\mathrm{N}=13 ; 18.05 \%)$, autoimmune hemolytic anemia $(\mathrm{N}=4 ; 5.6 \%)$ and autoimmune atrophic thyroiditis $(\mathrm{N}=2 ; 2.77 \%)$. Graves' disease was associated with type 1 diabetes in one patient. Systemic autoimmune diseases were Rheumatoid arthritis $(\mathrm{N}=4 ; 5.6 \%)$, systemic lupus erythematosus $(\mathrm{N}=3 ; 4.2 \%)$ and MCTD $(\mathrm{N}=1$; $1.38 \%$ ). Rheumatoid arthritis was associated with diabetes in one patient. MCTD was associated with atrophic thyroiditis in also one patient. This study shows that the autoimmune diseases in the Internal Medicine department of Sylvanus Olympio teaching hospital of Lomé are dominated by endocrinopathies namely type1 diabetes and Graves' disease.
\end{abstract}

Keywords: Autoimmune Diseases; Type 1 Diabetes; Grave's Disease; Lomé (Togo)

\section{Introduction}

Autoimmunity is the breakdown of tolerance mechanisms which leads to the pathogenic action of the immune system with respect to natural constituents of the organism and to the appearance of a so-called autoimmune disease [1]. Autoimmune diseases are a group of heterogeneous, rare, polymorphic diseases, in general of precise unknown etiologies and of multifactorial determinism with notably an environmental part and susceptibility genes [2]. Autoimmune diseases can be confined specifically to an organ or be systemic [3]. These, long ignored and under diagnosed in Africa, are increasingly described in recent years due to better knowledge of shapes in usual and misleading [4-6]. In Togo, few studies have been devoted to these autoimmune diseases in internal medicine departments.

\section{Aim of the Study}

The aim of this work was to describe the epidemiological profile and classification of these diseases in the Internal Medicine service of the Sylvanus Olympio teaching hospital in Lomé (Togo).

\section{Materials and Methods}

This is a retrospective study done in the Internal Medicine department of the Sylvanus Olympio teaching hospital in Lomé. It spread over a period of two years from $1^{\text {st } J a n u a r y ~} 2018$ to 31 De- cember 2019. Were included in this study, all the files of patients aged 16 and over who were hospitalized or consulted in the Internal Medicine service (Medicine B and medical clinic) for an autoimmune disease. Systemic autoimmune diseases were selected on the basis of their international consensus criteria. The diagnosis of systemic lupus erythematosus has been selected on the basis of at least 4 of the 11 criteria of the ACR (American College of Rheumatology) in 1997. That of the rheumatoid arthritis was selected on the basis of at least 4 criteria ACR (1987) and a score higher than 6 of ACR/EULAR (2010). Sharp's syndrome was suspected in a phenomenon of Raynaud, stubby fingers, myalgia, synovitis and a high rate of speckled anti-U1-RNP antibodies. Concerning organspecific autoimmune diseases, in the absence of immunology, type 1 diabetes was selected on the basis of a fasting blood sugar level greater than or equal to $1.26 \mathrm{~g} / \mathrm{l}$ two or three times, or a blood sugar at any time of the day greater than or equal to $2 \mathrm{~g} / \mathrm{l}$ two or three times or else a glycated hemoglobin greater than or equal to $6.5 \%$ associated with epidemiological arguments (young age) and clinical (normal or lean weight subject, good clinical progress and glycemic balance under insulin therapy). Graves' disease was mentioned to all patients of both sexes, presenting clinically bilateral exophthalmos; diffuse, firm, painless goiter with a thrill and a systolic murmur but without cervical and supraclavicular lymphade- 
nopathy and biologically: TSHus $<0.15 \mu \mathrm{UI} / \mathrm{ml}$, FT3 $>5.7 \mathrm{pmol} / \mathrm{l}$ and FT4 $>23.8$ pmol/l. Atrophic thyroiditis was retained before unilateral or bilateral lobar atrophy of the thyroid associated with hypoechogenicity and hypervascularization to thyroid ultrasound. Autoimmune hemolytic anemia was selected on the basis of a hemoglobin level lower than $13 \mathrm{~g} / \mathrm{dl}$ in men and $12 \mathrm{~g} / \mathrm{dl}$ in women associated with clinical arguments (jaundice, hemoglobinuria, splenomegaly) and biological arguments (LDH greater than 400 IU/l; positive COOMBS test).

\section{Results}

During our study period, 959 patients were received in the department. Of these, 72 had autoimmune disease, a prevalence of $7.5 \%$. Three patients presented an association of autoimmune diseases. The average age of the patients was 31.51 years (range: 17 and 74 ) and the sex ratio (M/F) was 0.46 . The 20 to 39 age group was the most represented (69.44\%). The organ specific autoimmune diseases were:

- Type 1 diabetes mellitus ( $N=48 ; 66.7 \%)$ : The average age of the patients was 26.1 years (range 17 and 41 ) and the sex ratio (M/F) was $0,8$.

- $\quad$ Graves' disease $(\mathrm{N}=13 ; 18.05 \%)$ : The average age of the patients was 37.77 years (range 17 and 53 years). It involved 12 women and one man.

- $\quad$ Autoimmune atrophic thyroiditis $(\mathrm{N}=2 ; 2.77 \%)$ : It was observed in a 48-year-old woman and a 28 -year-old man.

- Autoimmune hemolytic anemia $(\mathrm{N}=4 ; 5.6 \%)$ : It concerned only the female gender and the average age of patients was 36.5 years (range 29 to 42 years).

Systemic autoimmune diseases were encountered only in women $(\mathrm{N}=8 ; 11.11 \%)$. These were rheumatoid arthritis ( $\mathrm{N}=4 ; 5.6 \%)$ with an average age of 64.25 years (range 45 and 74 years), systemic lupus erythematosus ( $\mathrm{N}=3 ; 4.2 \%)$ with an average age of 28 years (range 18 and 34 ) and Sharp syndrome ( $N=1 ; 1.38 \%)$. Diabetes was associated with rheumatoid arthritis in one patient and Graves' disease in one patient as well. Sharp syndrome was also associated with atrophic thyroiditis in one patient.

\section{Discussion}

The prevalence of autoimmune diseases in our study was 7.5\%. This prevalence is certainly underestimated due to the insufficiency of the technical platform, in particular the unavailability of immunological examinations, most of them being done abroad. Despite the partnership of some private laboratories of our country with French structures, the cost of these examinations always comes back expensive for the majority of our patients with low purchasing power. However, in recent years, the prevalence of these autoimmune diseases has increased steadily in some African countries [3]. Our study population was young. This same observation has been made by several authors [4-7]. The preponderance of women observed in our series is also consistent with data from the literature [2-7]. Organ-specific autoimmune diseases were the majority in our series dominated by endocrinopathies. Indeed the endocrine glands constitute a privileged target of autoimmunity [8].
Among these endocrinopathies, type 1 diabetes mellitus observed in very young patients ranked the first place in our study population. Type 1 diabetes mellitus is associated with a chronic autoimmune response against beta cells in the pancreas. This autoimmunity begins very early in life and diabetes appears a few years later, often in childhood and adolescence and sometimes in adulthood [9]. The early or late onset of the disease would depend on the antibody involved. The presence of anti-islet Langerhans antibodies in a child at a titer greater than 20 units JDF announces the onset of diabetes within 7 years [9]. The detection of anti-tyrosine - phosphate antibodies (IA-2) would give a positive predictive value of 75 to $100 \%$ over the next 5 years in populations at risk [9]. Regarding sex, a slight predominance of females was observed in our series as in that of Fangbémi., et al. in Benin [10] and that of Timotéo., et al. in Portugal [11]. In contrast, in the study of Jarosz Chobot., et al. [12] in Poland, the male sex was the most represented. The female sex would not be a predisposing factor in type 1 diabetes as it is in most autoimmune diseases. Graves' disease mainly encountered in women with an average age of 37.77 years was the second autoimmune endocrinopathy observed in our study population. Our average age is similar to that of Mbadinga., et al. in Congo (37 years) [13]. An average age of 31.8 years has been reported in a series in Togo [14] and 34 years in a French series [15]. Graves' disease mainly affects young people. Several studies have also reported a clear predominance of women [13-17]. The female sex is a predisposing factor for Graves' disease. An association of type 1 diabetes and Graves' disease was observed in one of our patients, thus entering into the context of an autoimmune polyendocrinopathy type IIIa [9]. The hemolytic autoimmune anemia was the $3^{\text {rd }}$ organ-specific autoimmune disease in our study. The female predominance found in our patients is also reported in a French series $(71.4 \%)$ [18]. On the other hand, this anemia concerned the young subjects in our series unlike the French series [18] which estimates that the elderly subjects are the most affected (average age of 68.27 years). The atrophic thyroiditis was the last organ-specific autoimmune disease in our patients. In reality, the atrophic thyroiditis is also of autoimmune origin but there is no goiter and the anti-thyroid antibodies are often lower or negative [19]. It often constitutes the evolution of Hashimoto's disease and occurs later willingly after 50 years, after menopause in women [19]. But one of our two patients was a male.

Among the systemic autoimmune diseases found in our study, rheumatoid arthritis affecting only the female sex was slightly predominant. Its predominance has also been reported in Senegal by Kane., et al [20]. Its frequency is 2 cases per year in our service. This frequency is close to that reported in rheumatology in Lomé, i.e. around 4 cases per year [21]. But the frequency of rheumatoid arthritis in our country would certainly be underestimated since many patients are engaged in traditional medicine and self-medication. Our patients were mainly elderly subjects contrary to the data in the literature which estimates that the age of predilection of the disease would be between 40 and 60 years [21-23]. Systemic lupus erythematosus was the second systemic autoimmune disease in our study population as in Kane series [20]. Its preponderance in female is well known $[20,24]$ and it concerned young subjects in 
our series confirming the data of the literature [24-26]. Sharp syndrome closed the door on systemic autoimmune diseases in our patients. Really, the MCTD is a rare entity in the black subject in general and particularly in the African black, the reason could be genetics [27-29]. Demographic and clinical aspects appear similar in Caucasians, Asians and blacks except for a low frequency of Raynaud's phenomenon in blacks [27].

\section{Conclusion}

Autoimmune diseases in Internal Medicine service (Medicine B and Medical Clinic) of Sylvanus Olympio teaching hospital are multiple but their frequency is underestimated due to lack of specific self-antibodies dosage for lack of technical platform. They are nevertheless dominated by autoimmune endocrinopathies, in this case type 1 diabetes and Graves' disease. An improvement in our technical platform and health insurance for everyone in our country will allow early diagnosis, especially of minor forms, and better therapeutic management of these diseases.

\section{Bibliography}

1. Kouassi E., et al. "Système immunitaire". Environnement Et Santé Publique (2003): 687-698.

2. Cooper GS., et al. "Rescent insights in the epidemiology of autoimmune diseases: Improved prevalence estimates and understanding of clustering of diseases". Journal of Autoimmunity 33 (2009): 197-207.

3. Ka M M., et al. "La problématique des Maladies Auto-immunes en Afrique". RAFMI 4.1-1 (2017): 7-8.

4. Kane BS., et al. "Maladies systémiques en médecine interne "contexte africain": aspects épidémiologiques et classification". La Revue de Médecine Interne 37.1 (2016): 37.

5. Mijiyawa M., et al. "Les connectivites en consultation hospitalière à Lomé (Togo)". La Revue de Médecine Interne 20.1 (1999): 13-17.

6. Ouédraogo DD., et al. "Les connectivites en pratique hospitalière à Ouagadougou". Médecine et Santé Tropicales 24.3 (2014): 271-274.

7. Dioussé P., et al. "Profil épidémio-clinique des maladies autoimmunes systémiques dans un service de Dermatologie". RAFMI 4.2 (2017): 18-21.

8. Wemeau JL and Proust-Lemoine E. "Polyendocrinopathies auto-immunes de type 1: Caractéristiques cliniques et évolutives sur la base d'une enquête inter-régionale et nationale". Bulletin de L'Académie Nationale de Médecine 197.1 (2013): 19-30.

9. Humbel RL. "Maladies auto-immunes des glandes endocrines". GEAI L'info 5 (2002): 1-23.

10. Fagbemi KA., et al. "Aspects épidémiologiques du diabète de type 1 à la banque d'insuline de Cotonou (Bénin)". International Journal of Biological and Chemical Sciences 11.3 (2017): 1085-1095.
11. Timóteo C., et al. "Growth and puberty in type 1 diabetes mellitus - experience from a pediatric endocrinology unit". Acta Medica Portuguesa 25.4 (2012): 213-218.

12. Jarosz-Chobot P., et al. "Rapid increase in the incidence of type 1 diabetes in Polish children from 1989 to 2004, and predictions for 2010 to 2025". Diabetologia 54.3 (2011): 508-515.

13. Mbadinga H., et al. "Nsakala-kibangou N.: hyperthyroïdies : aspects étiologiques et cliniques étude de 72 cas au chu de Brazzaville (Congo)". Médecine d'Afrique Noire 44 (1997): 342-344

14. Balaka A., et al. "La maladie de Basedow : aspects épidémiologiques, diagnostiques et évolutifs au CHU Sylvanus Olympio de Lomé". Rev Afr End Métab Nut 3.2 (2016): 6-9.

15. Bilosi M., et al. "La thyroïdectomie subtotale bilatérale de réduction reste-t-elle indiquée dans la maladie de Basedow?" Annales de Chirurgie 127.2 (2002): 115-120.

16. Wemeau JL. "Hyperthyroïdie: étiologie, physiopatologie, diagnostic, évolution, traitement". La Revue du Praticien 48.12 (1998): 1377-1384

17. Lokrou A., et al. "Aspects cliniques, hormonaux et thérapeutiques de la maladie de Basedow à Abidjan: étude préliminaire à partir de 6 cas". Médecine d'Afrique Noire 35.7 (1988): 555558.

18. Zulfiqar AA., et al. "Anémie hémolytique auto-immune: Expérience de deux services de médecine interne". La Revue de Médecine Interne 37.1 (2016): A131-A132.

19. Hadj Kacem F., et al. "Démarche diagnostique et thérapeutique d'une hypothyroïdie primaire". J.I. M. Sfax 29 (2018): 9-17.

20. Kane BS., et al. "Maladies systémiques en médecine interne "contexte africain": aspects épidémiologiques et classification". La Revue de Médecine Interne 37 (2016): A37.

21. Kakpovi K., et al. "Profil de la polyarthrite rhumatoïde en consultation rhumatologique à Lomé (Togo)”. European Scientific Journal 13.15 (2017): 125-132.

22. Malemba JJ., et al. "The epidemiology of rheumatoid arthritis in Kinshasa, Democratic Republic of Congo. A populationbased study". Rheumatology 51 (2012): 1644-1647.

23. Atouf 0., et al. "Polymorphisme HLA et polyarthrite rhumatoïde précoce dans la population marocaine". Revue du Rhumatisme 75 (2008): 824-830.

24. Kombate K., et al. "Le lupus systémique à Lomé, Togo". Tropical Medicine and Health 68 (2008): 283-286.

25. Diop M M., et al. "Les modes de révélation du lupus érythémateux systémique à Dakar (Sénégal) : à propos d'une série de 161 cas". RAFMI 1.44 (2014): 12-15. 
26. Lopez P., et al. "Epidemiology of systemic lupus erythematosus in northern Spanish population : Gender and age affluence on immunological features". Lupus 12.11 (2003): 860-865.

27. Missounga L., et al. "La connectivite mixte: prévalence et caractéristiques cliniques chez le noir africain, étude de 7 cas au Gabon et revue de la littérature". The Pan African Medical Journal 27 (2017): 162.

28. Houzou P., et al. "Rheumatic diseases profile of 13577 West African patients”. Journal Medical Tunisie 91.01 (2013): 16-20.

29. Ouedraogo DD., et al. "Les connectivites en pratique hospitalière à Ouagadougou (Burkina Faso)". Médecine et Santé Tropicales 24.3 (2014): 2714 .

\section{Assets from publication with us}

- Prompt Acknowledgement after receiving the article

- Thorough Double blinded peer review

- Rapid Publication

- Issue of Publication Certificate

- High visibility of your Published work

Website: https://www.actascientific.com/

Submit Article: https://www.actascientific.com/submission.php

Email us: editor@actascientific.com

Contact us: +919182824667 